\title{
EVOLUTION OF AGRICULTURAL MECHANIZATION IN VIET NAM
}

\section{Hiroyuki Takeshima, Yanyan Liu, Nguyen Van Cuong, and Ian Masias}

\begin{abstract}
Despite the reportedly rapid growth of mechanization, as well as its unique history in economic and social systems, information on the patterns of agricultural mechanization growth in Viet Nam has been limited. Through an extensive review of existing literature and several rounds of nationally representative household survey data, we document the evolution of mechanization (particularly with tractors and combine harvesters) in Viet Nam, including the heterogeneity across regions and farm sizes, and the emerging roles of the private sector in the supply of machinery and hiring services. The historical growth pattern of mechanization in Viet Nam had been nonlinear, characterized by somewhat high tractor use prior to 1975 , followed by a decline in the 1980s before a resurgence in the 1990s, with considerable variations in adoption patterns across regions. Since the economic and social reform in the late 1980s, the private sector has rapidly emerged as the major player in meeting the demand for greater farm power uses, including the domestic manufacturing of power tillers, the introduction of larger combine harvesters, and the emergence of individual machine owners as the primary suppliers of hiring services. Although machinery use has gradually spread from larger farms to smaller farms, there are some signs that the comparative advantage has been shifting toward larger farms.
\end{abstract}

\section{Introduction}

Viet Nam has reportedly experienced rapid growth in agricultural mechanization lately, particularly in the use of tractors and combine harvesters (Pingali 2007; Reardon et al. 2014). The recent growth in mechanization has been similar to that of other developing countries in Asia. However, in the long term, the historical growth of agricultural mechanization has been unique due to the considerable changes in the political and economic systems in Viet Nam, which few other countries in Southeast Asia or South Asia have experienced. 
Documentation of the key agricultural mechanization patterns in Viet Nam is limited and large knowledge gaps exist. There has been little information on the actual extent of mechanization prior to 1975, in particular the use of tractors in Viet Nam. Understanding such historical patterns is important in assessing how the early exposures to tractors might have contributed to their spread in later decades. There is also little information available regarding the subnational variations in machine adoption, including that of tractors and combine harvesters. Last, little documentation exists on how the supply of machines and hiring services is emerging in Viet Nam. Understanding such supply-side development is important in assessing how the public-sector policies and the private sector have contributed to mechanization growth.

This chapter fills such knowledge gaps and documents the evolution of the growth of mechanization in Viet Nam based on an extensive review of the existing literature and several rounds of a nationally representative household survey. The available evidence suggests that the level of tractor use in Viet Nam had been relatively high in the 1970s and the early 1980s, but declined through the late 1980s before it started taking off again in the 1990s. The relatively high level of tractor use up to the early 1980 s was partly for political and military reasons, because both the West and the Soviet Union gave the country substantial support in providing heavy machinery, including tractors. We also find that the mechanization growth pattern has been heterogeneous within the country, with distinctions between the relatively smallholder-dominated deltas and the land-abundant central coast regions. Based on the literature review, we also find that the private sector-led hiring services have been increasingly overtaking the public and cooperative-based service providers, consistent with the patterns elsewhere in Asia, including countries like China with relatively stronger socialist structures of the economy (Zhang, Yang, and Reardon 2017).

This chapter contributes to the literature on agricultural mechanization by providing a focused, in-depth description of the evolutionary pattern of agricultural mechanization in Viet Nam and its subregions. It builds on the past and emerging literature that focuses on providing holistic perspectives on the spread of agricultural mechanization and the development of relevant sectors, rather than an analysis of specific causal mechanisms (IRRI 1978, 1983, 1986; Kienzle, Ashburner, and Sims 2013; Mandal, Biggs, and Justice 2017). The chapter also provides important historical perspectives and contexts for studies that focus on the more recent agricultural mechanization issues in Viet Nam (for example, Liu, Violette, and Barrett 2016).

The evolution of agricultural mechanization in Viet Nam has not been linear. The significant changes in the levels of mechanization, particularly in the 
use of tractors and combine harvesters, are partially associated with key historical events that changed the political and economic systems in the country over the last half-century. Table 6.1 shows a back-of-the-envelope approach to estimating the levels of mechanization based on a detailed review of existing studies that have not been widely chronicled in the existing mechanization literature. It also summarizes rough indicators of the economy and agricultural transformation. Viet Nam's recent history of agricultural mechanization can be roughly grouped into four phases: (1) until around 1975 (before reunification); (2) around 1975 to approximately the 1980s: collectivized production; (3) around 1990 to around 2010: liberalization and expansion of power tiller and medium-size 20-35 hp tractor use; (4) around 2010 and after: deepened mechanization growth through large tractors and combine harvesters.

The chapter is structured in the following way. The next section provides a qualitative analysis of the factors driving the spread of mechanization and the variations across the regions within the country. After that, the chapter briefly describes the emerging patterns in the supply of machinery and mechanization services. The last section provides concluding messages. ${ }^{1}$

\section{Descriptive Analysis of the Growth Pattern of Mechanization}

This section provides detailed descriptive evidence of the growth pattern of mechanization in Viet Nam between recent periods, using several rounds of the Vietnamese Living Standard Survey (VLSS), which was later renamed Vietnamese Household Living Standard Survey (VHLSS), since 2002 (GSOV 2016). Hereafter, we refer to both VLSS and VHLSS as "VHLSS." For a detailed description of the VHLSS, see Liu, Violette, and Barrett (2016).

\section{Subnational Variations in Machine Rental and Ownership}

The recent machinery use patterns in Viet Nam have been consistent with the hypothesis that mechanization growth tends to be faster in areas with favorable agricultural environments (for example, lowland areas such as deltas). Table 6.2 reports proportions of farm households that rented machinery by region and their changes between 1992 and $2008 .^{2}$ The Mekong and

1 This chapter is a shortened version of Takeshima and others (2018), which also contains more detailed descriptions of the historical evolution of mechanization in the country.

2 Although the VHLSS does not report detailed descriptions of how machines were used by households, tractors in Viet Nam have typically been used for land preparation and transportation.

For example, tractors are used for land preparation on rice plots in the following way. For the 


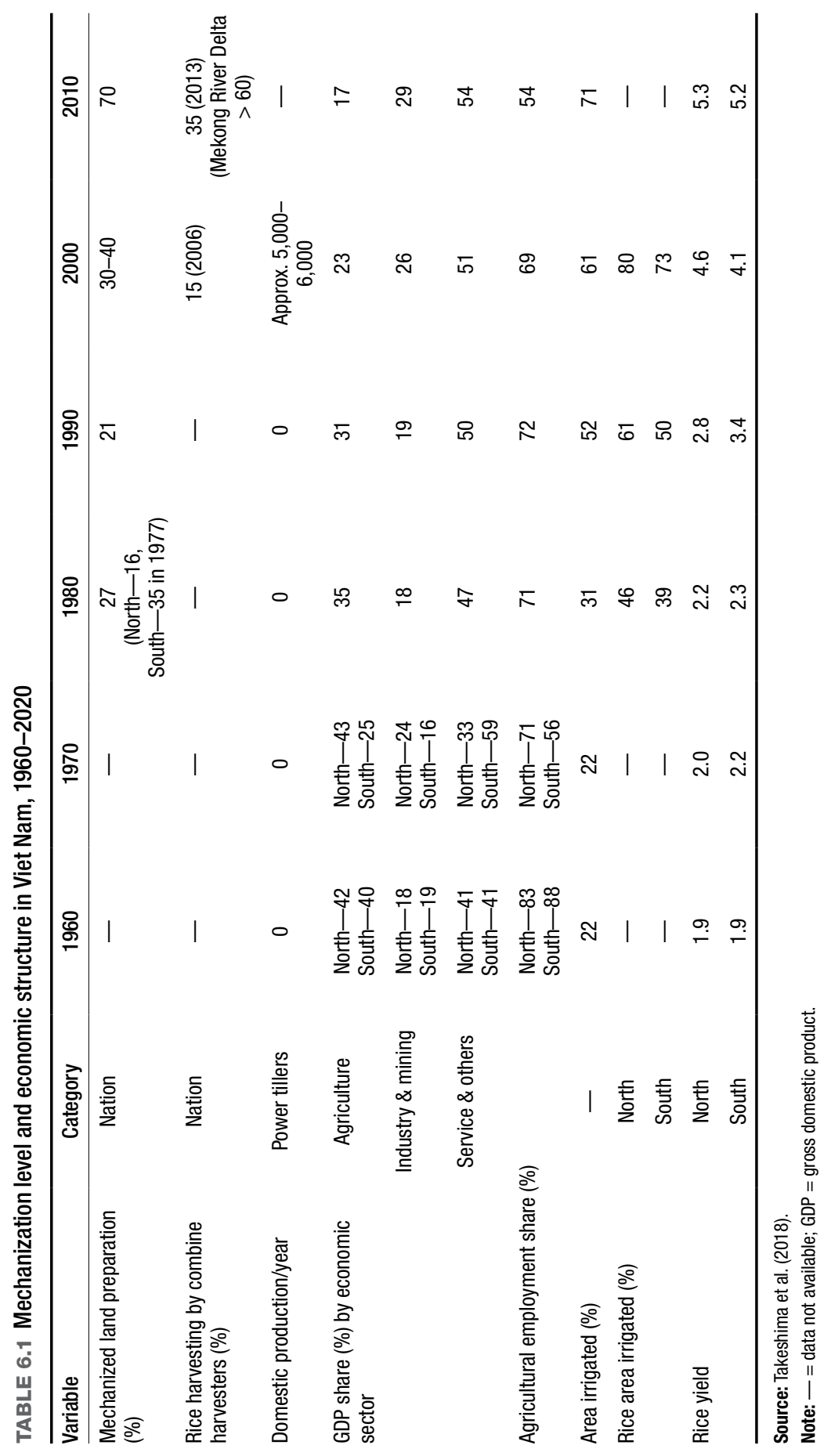


Red River Deltas are the main regions of rice production and the most populated areas in Viet Nam. The Mekong River Delta had the highest machinery rental rate (49 percent) in 1992 and has remained one of the most mechanized areas since. However, the Red River Delta became the most prevalent machinery rental region from 2004 to 2008 (with 80-85 percent of total rentals). Machinery rental has also grown substantially in the Central Highlands, increasing to 55 percent in 2008 (Table 6.2). This region has the lowest population density and is the main production area for cash crops (Table 6.3). The pattern in the Central Highlands has been consistent with the hypothesis that mechanization helps the growth of larger farms in relatively landabundant areas where market access is good. Unsurprisingly, the mountainous Northwest region had the lowest rate, at 27 percent in 2008.

Table 6.4 reports the proportion of households that owned tractors by region from 1992 to 2008. Tractor ownership was consistently low except for the Central Highlands, where about 13 percent of households owned tractors in 2008. In other regions, tractor-owning households accounted for less than 2 percent of households in 2008. There are also slight variations in the major types of tractors across regions (Table 6.5). Whereas the majority of tractors owned in 2007 in all regions were 2WTs with less than $12 \mathrm{hp}$, the South Central Coast, Central Highland, and Mekong Delta were relatively more populated with $4 \mathrm{WTs}$ of greater than $12 \mathrm{hp}$. In particular, 7.5 out of 1,000 farm households in the Mekong Delta owned larger 4WTs with horsepower greater than 35 . This was substantially higher than the national average of 1.7 out of 1,000 farm households.

Table 6.2 and Table 6.4 together indicate that a significant share of tractor adoptions have been achieved through rentals rather than ownership. This has applied not only to the expensive 4WTs but also the relatively cheaper 2WTs.

first rice crop, before sowing the germinated seeds, farmers muddy and level the land because the soil is wet after the flooding season. For the second rice crop, if only two rice crops are being planted in that year, they plow, muddy, and level the land. However, if they are planting three annual rice crops, they may not plow the land and may instead burn the rice straw left in the field because time for land preparation is very short in this rice season. Then, if there is a third rice crop, they again plow, muddy, and level the land (Tuyến 2013).

For transportation, four-wheel tractors (4WTs) and two-wheel tractors (2WTs) are typically used in the following way. In Viet Nam, tractors used for transportation are often called xe cay for a 4WT and công nong for a 2WT. Fitted with trailers, 2WTs (côngnong) are often used to ship around 2 tons of goods per trip to trading hubs at the commune center that are as far as $10 \mathrm{~km}$ away, although for a distance of more than $500 \mathrm{~m}$, farmers may use motorbikes or animal traction (horses, buffalo) rather than 2WTs (Lançon, Sautier, and Anh 2014). Many village collectors reportedly own 2WTs with such a 2 ton-capacity trailer (Lançon, Sautier, and Anh 2014). Transport costs in districts such as Krông Nô are generally around 10 Vietnamese dong (VND)/ $\mathrm{kg} / \mathrm{km}$ (about $0.04 \mathrm{US}$ cents), although some farmers in the more remote areas pay around 40 $\mathrm{VND} / \mathrm{kg} / \mathrm{km}$ (Lançon, Sautier, and Anh 2014). 
TABLE 6.2 Proportion of machine rental by region, Viet Nam, 1992-2008

\begin{tabular}{lcccccc}
\hline Region & 1992 & 1998 & 2002 & 2004 & 2006 & 2008 \\
\hline Red River Delta & 0.130 & 0.577 & 0.705 & 0.803 & 0.816 & 0.853 \\
Northeast & 0.005 & 0.269 & 0.210 & 0.305 & 0.383 & 0.421 \\
Northwest & 0.110 & 0.168 & 0.190 & 0.230 & 0.288 & 0.272 \\
North Central Coast & 0.260 & 0.300 & 0.585 & 0.659 & 0.679 & 0.727 \\
South Central Coast & 0.114 & 0.457 & 0.629 & 0.675 & 0.702 & 0.761 \\
Central Highlands & 0.033 & 0.380 & 0.376 & 0.588 & 0.535 & 0.546 \\
Southeast & 0.063 & 0.489 & 0.431 & 0.507 & 0.444 & 0.459 \\
Mekong River Delta & 0.491 & 0.699 & 0.713 & 0.742 & 0.690 & 0.668 \\
\hline
\end{tabular}

Source: Authors' estimations based on Vietnamese Household Living Standard Survey.

TABLE 6.3 Median total land cultivated per household (in square meters) by region, Viet Nam, 1992-2008

\begin{tabular}{lrrrrrr}
\hline Region & $\mathbf{1 9 9 2}$ & $\mathbf{1 9 9 8}$ & $\mathbf{2 0 0 2}$ & $\mathbf{2 0 0 4}$ & $\mathbf{2 0 0 6}$ & \multicolumn{1}{c}{$\mathbf{2 0 0 8}$} \\
\hline Red River Delta & 2,442 & 2,376 & 2,160 & 2,052 & 1,980 & 1,946 \\
Northeast & 3,700 & 3,395 & 3,600 & 3,310 & 3,314 & 3,240 \\
Northwest & 8,899 & 7,400 & 7,840 & 7,352 & 9,000 & 8,200 \\
North Central Coast & 2,701 & 2,559 & 2,800 & 2,773 & 2,825 & 2,545 \\
South Central Coast & 2,565 & 2,847 & 2,500 & 2,474 & 2,500 & 2,500 \\
Central Highlands & 8,500 & 9,700 & 10,000 & 10,000 & 10,200 & 10,350 \\
Southeast & 7,000 & 7,775 & 7,100 & 8,000 & 8,000 & 7,000 \\
Mekong River Delta & 7,800 & 7,400 & 6,400 & 6,435 & 6,000 & 6,000 \\
\hline
\end{tabular}

Source: Authors' calculations based on Vietnamese Household Living Standard Survey.

The growth of machine rentals has been observed across many regions, including northern Viet Nam, where the use of rented 2WTs was less common than in southern Viet Nam in the 1990s (Minot and Goletti 2000, 14).

Importantly, the growth in tractor use in Viet Nam since the 1990s is likely to have been the result of rising demand for overall farm power use, rather than substitution for manual farm power. Figure 6.1 plots the proportion of households that owned tractors, rented machinery, or hired labor from 1992 to 2008. Although we do not see much change in tractor ownership, the percentage of cultivating households that rented machines more than tripled, from 19 percent in 1992 to 63 percent in 2008. The percentage of households that hired labor also increased sharply, from 32 percent in 1992 to 55 percent in 2008 . 
TABLE 6.4 Tractor ownership by region, Viet Nam, 1992-2008

\begin{tabular}{lcccccc}
\hline Region & 1992 & 1998 & 2002 & 2004 & 2006 & 2008 \\
\hline Red River Delta & 0.001 & 0.002 & 0.008 & 0.010 & 0.006 & 0.008 \\
Northeast & 0.003 & 0.004 & 0.009 & 0.012 & 0.011 & 0.012 \\
Northwest & 0.000 & 0.000 & 0.006 & 0.000 & 0.003 & 0.000 \\
North Central Coast & 0.002 & 0.002 & 0.010 & 0.006 & 0.009 & 0.002 \\
South Central Coast & 0.003 & 0.012 & 0.007 & 0.010 & 0.010 & 0.009 \\
Central Highlands & 0.099 & 0.212 & 0.099 & 0.116 & 0.125 & 0.128 \\
Southeast & 0.014 & 0.069 & 0.025 & 0.025 & 0.025 & 0.020 \\
Mekong River Delta & 0.016 & 0.028 & 0.014 & 0.021 & 0.018 & 0.020 \\
\hline
\end{tabular}

Source: Authors' estimations based on Vietnamese Household Living Standard Survey.

TABLE 6.5 Tractors per 1,000 farm households, by region, Viet Nam, 2007

\begin{tabular}{lccc}
\hline Region & $<12 \mathrm{hp}$ & $12-35 \mathrm{hp}$ & $>35 \mathrm{hp}$ \\
\hline Red River Delta & 14.9 & 3.1 & 0.3 \\
Northeast & 28.3 & 3.3 & 0.3 \\
Northwest & 9.0 & 1.1 & 0.4 \\
North Central Coast & 12.3 & 3.4 & 0.9 \\
South Central Coast & 9.2 & 4.6 & 4.0 \\
Central Highland & 97.8 & 56.8 & 5.8 \\
Southeast & 23.2 & 10.6 & 3.5 \\
Mekong River Delta & 21.8 & 7.5 & 7.5 \\
Total & 24.3 & 8.8 & 1.7 \\
\hline
\end{tabular}

Source: Tsukada (2012, Table 3).

\section{Farm Size and Machinery Use}

Another important pattern of mechanization is the considerable spread among smallholders. Such patterns have been reported for other Asian countries, but not for Viet Nam.

Based on rice planting area, we categorize farmers into two equal groups: "smaller-holders," cultivating less than 5,760 square meters of rice area, and "larger-holders," cultivating more than 5,760 square meters of rice area. Figure 6.2 plots tractor ownership and machine rental from 1992 to 2008 for these two groups. Larger-holders and smaller-holders have similarly low levels of machine ownership, compared with the levels of machine use through rentals, indicating that not only smaller-holders but also most larger-holders in Viet Nam have relied on rented machines rather than owned machines. 
FIGURE 6.1 Trend of tractor ownership, machine renting, and labor hiring for all farming operations in Viet Nam, 1992-2008

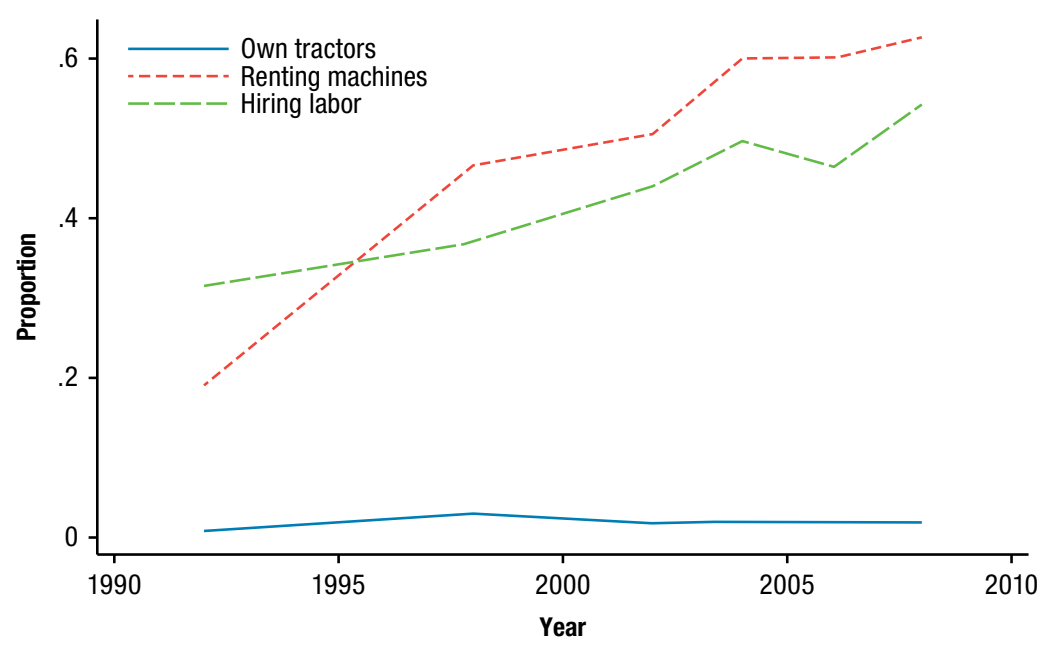

Source: Authors' calculations based on Vietnamese Household Living Standard Survey.

Note: Proportion is in terms of households, and not weighted by areas.

Whereas larger-holders have had a higher propensity to rent machines throughout the period, the difference between the two groups has decreased over time, especially in the late 2000s, indicating that smaller-holders have also been able to benefit from machine rentals.

Figure 6.3 shows the relationship between tractor ownership and rice planting area for 1992 and 2008, estimated through a nonparametric regression. The dotted lines show the 95 percent confidence intervals around the point estimates. In 1992, tractor ownership had been mostly concentrated among very large farms cultivating more than 20,000 square meters (approximately 10 in the natural $\log$ ), although the large confidence intervals suggest the estimation was not precise. In 2008, whereas large farms still exhibited a slightly higher rate of tractor ownership than small farms, the tractor ownership seemed to spread relatively more evenly across farms of different sizes. Although tractor ownership remained low, as mentioned above, Figure 6.3 suggests it has relatively increased among small farms lately. 
FIGURE 6.2 Tractor ownership and machine rental for larger- and smaller-holders, based on rice planting area, Viet Nam, 1992-2008

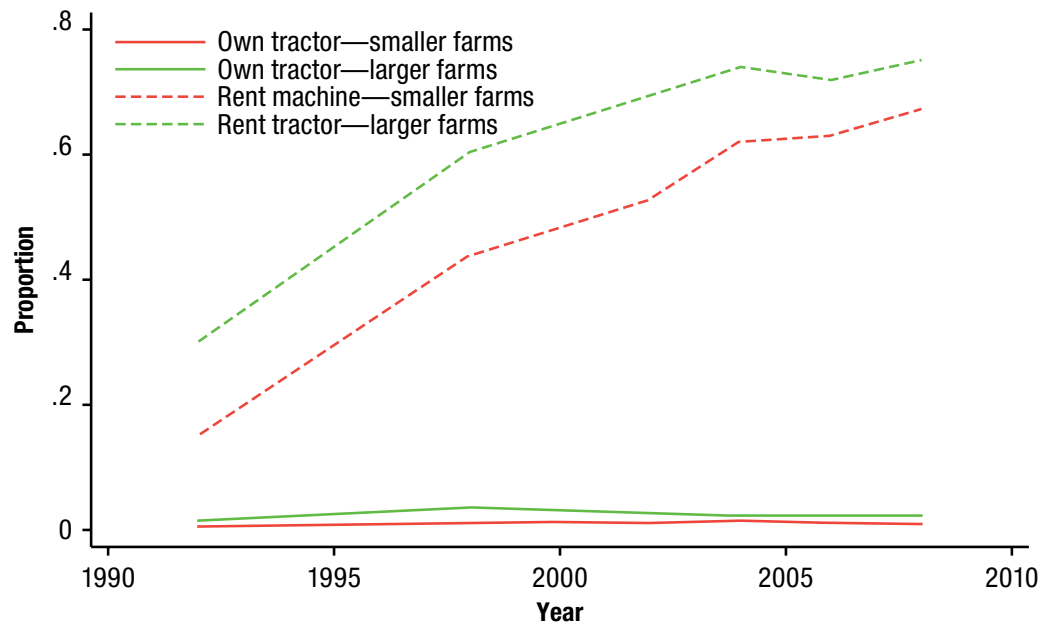

Source: Authors' calculations based on Vietnamese Household Living Standard Survey.

FIGURE 6.3 Relationship between tractor ownership and rice planting area, Viet Nam, 1992 and 2008

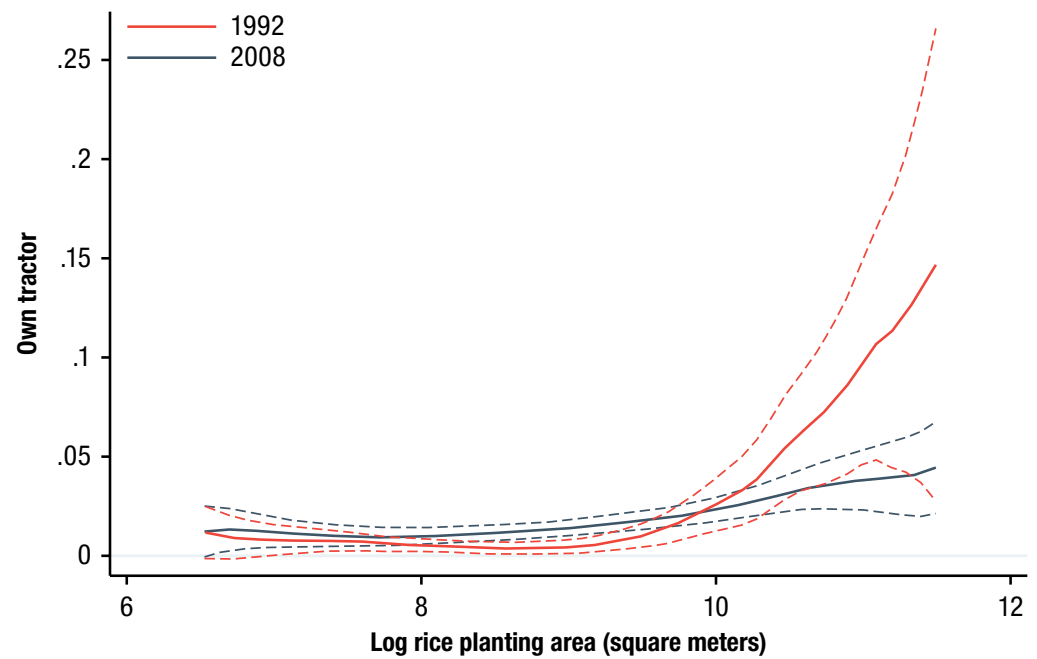

Source: Authors' calculations based on Vietnamese Household Living Standard Survey.

Note: Red dashed lines represent 95\% confidence intervals for 1992 line. Green dashed lines represent 95\% confidence intervals for 2008 line. 
Figure 6.4 illustrates a similar trend as Figure 6.3, but in the case of machine rentals. ${ }^{3}$ Machine rentals are significantly positively associated with farm size in both 1992 and 2008. This indicates that the complementarity between land and machines has remained important. However, the slope of the curve for 2008 is flatter than the slope of the curve for 1992, suggesting that machine rental has increased more among small farms.

It is important to note that the complementarity between land size and use of machines remains potentially influential. This is because, during 1992 and 2008, when tractor use grew considerably, the production intensity of rice, which is often the most mechanized crop among smallholders in Asia, also rose more, relative to the production of other crops.

Figure 6.5 depicts the mean and median of the total land cultivated per household and the total annual cropland cultivated per household from 1992 to 2008. Although the mean of landholdings was relatively stable over time, the median fell slightly at a steady pace over this period, suggesting a change in the landholding distribution. Figure 6.6 and Figure 6.7 depict the distribution of total cultivated land and annual cropland for 1992 and 2008. Both figures show similar patterns of distributional change from 1992 to 2008: the percentage of medium-sized farms fell, and there was a slight increase in percentage for both small farms and large ones. In contrast, the total rice planting area increased for all farm size percentiles over this period, showing a pattern different from that of total cultivated area across all crops (Figure 6.8). This difference may be attributed to increased intensification in rice production. Indeed, the proportion of irrigated annual land increased from 57 percent in 1992 to 81 percent in 2008, allowing for rice to be planted in more cropping seasons within a year. Similarly, in one of the most mechanized regions, the average farm size among the VLSS and VHLSS sample households increased from 1.0 ha in 1996 to 1.4 ha in 2009 in the Mekong River Delta.

Relatedly, Liu, Violette, and Barrett (2016) showed that although rice yield was significantly negatively associated with farm size (with an inverse relationship of farm size and land productivity) in the early 1990s, that relationship had largely disappeared by 2008 , indicating that the complementarity between landholdings and machine use has started becoming more effective. This finding is consistent with the patterns in many other Asian countries

3 Machine rental is proxied by whether the household incurred expenses for rental of assets, machinery, equipment, or means of transport. The VHLSS do not provide information on machine rental by type of machine or farming activity. 
FIGURE 6.4 Relationship between machine rental and rice planting area, Viet Nam, 1992 and 2008

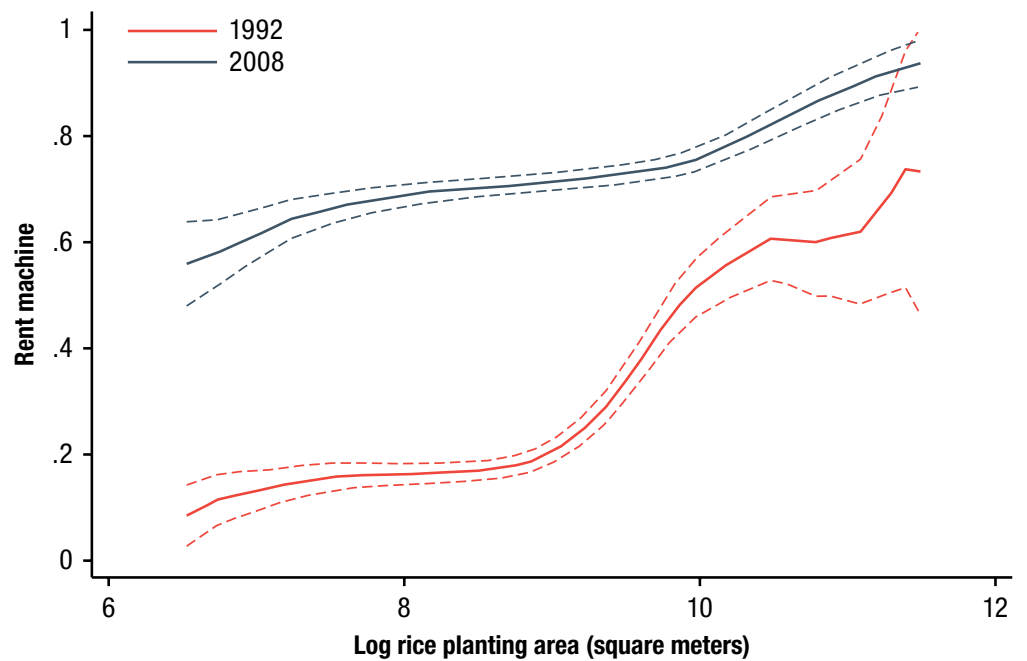

Source: Authors' calculations based on Vietnamese Household Living Standard Survey.

Note: Red dashed lines represent 95\% confidence intervals for 1992 line. Green dashed lines represent 95\% confidence intervals for 2008 line.

FIGURE 6.5 Trend of total land cultivated per household and total annual cropland cultivated per household, Viet Nam, 1992-2008

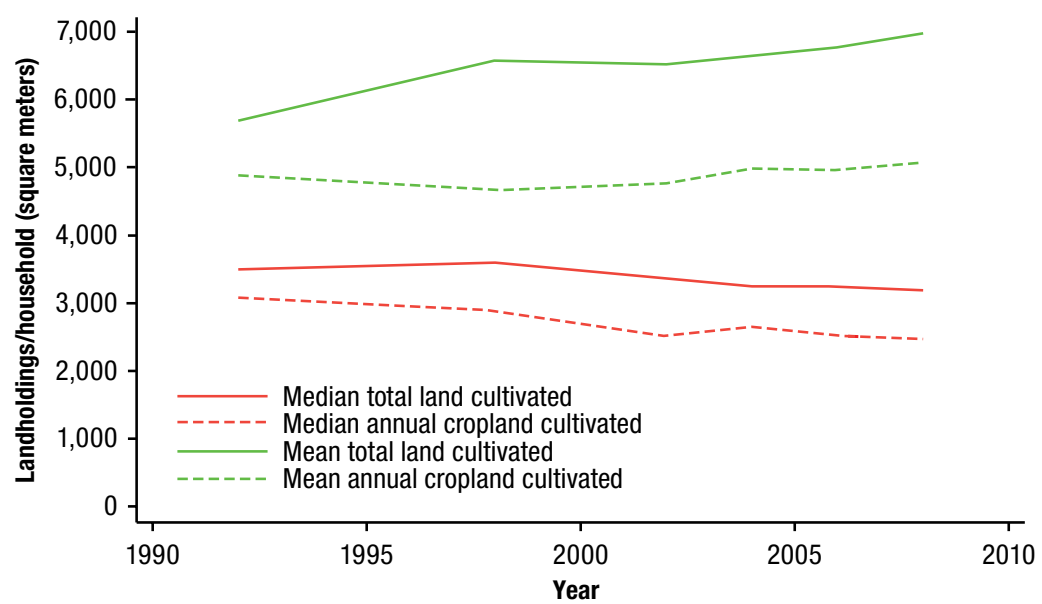

Source: Authors' calculations based on Vietnamese Household Living Standard Survey. 
FIGURE 6.6 Kernel density of total cultivated area, Viet Nam, 1992 and 2008

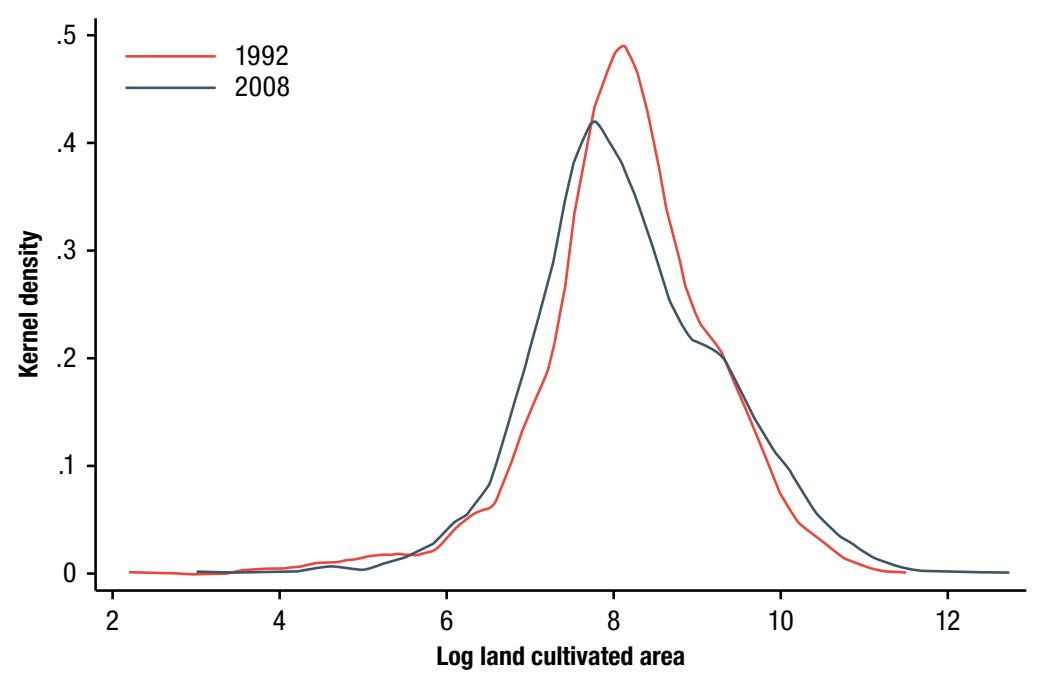

Source: Authors' calculations based on Vietnamese Household Living Standard Survey.

FIGURE 6.7 Kernel density of total annual cropland, Viet Nam, 1992 and 2008

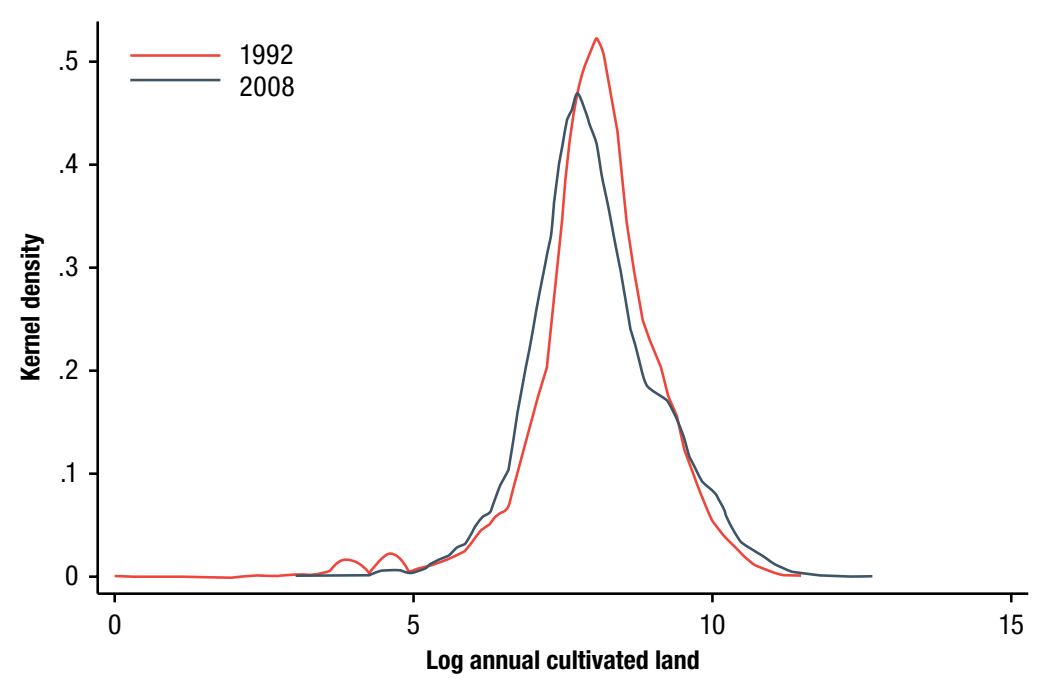

Source: Authors' calculations based on Vietnamese Household Living Standard Survey. 


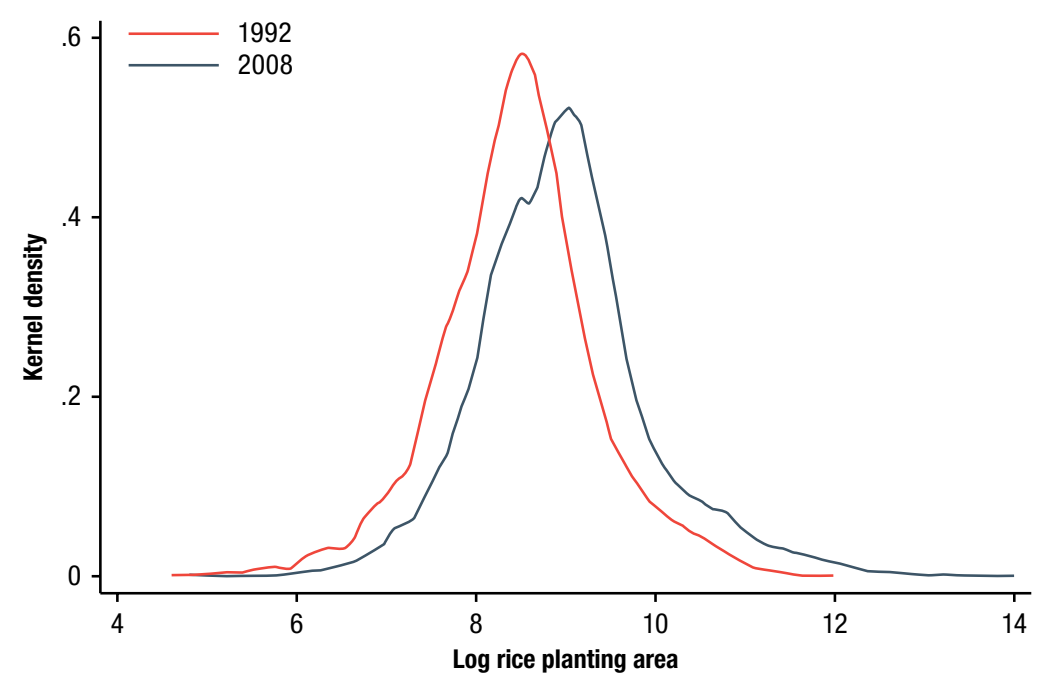

Source: Authors' calculations based on Vietnamese Household Living Standard Survey.

(Foster and Rosenzweig 2011; Yamauchi 2016). Although the spread of tractor use has benefited smallholders as much as larger farmers, further intensification of mechanization may gradually shift the comparative advantages to larger farmers and have serious implications on the future of smallholders in Viet Nam.

\section{Wages and Mechanization Growth}

As mentioned above, increased machinery use in Viet Nam is likely to have been the result of increased overall demand for farm power, as is indicated by the positive associations between the share of farm households using machines and those hiring labor (Figure 6.1). Nevertheless, it is important to note that rising wages have also been important drivers of the growth of mechanization.

Figure 6.9 plots the median female and male real agricultural wages from 1992 to 2008 . Real wages increased significantly from 1992 to $1998^{4}$ and lev-

4 This period in Viet Nam also saw an increasing rural-urban wage gap, explained by the returns on skills (Nguyen et al. 2007), and also marked the beginning of the decline in the agricultural share of employment (Table 6.1). 
FIGURE 6.9 Median daily real male and female agricultural wage, Viet Nam, 1992-2008

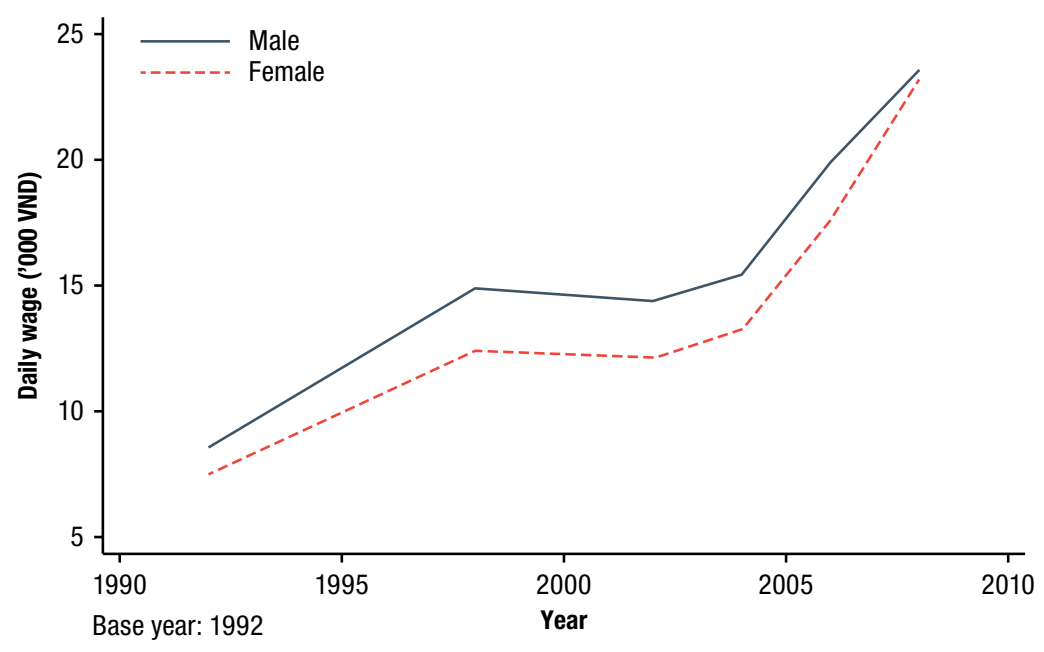

Source: Authors' calculations based on Vietnamese Household Living Standard Survey. Note: VND = Vietnamese dong.

eled off from 1998 to 2004, probably reflecting the lagged effects of the Asian financial crisis of $1997 / 1998$. From 2004 to 2008 , the real wage again picked up rapidly, at a rate even faster than that seen during 1992-1998. Table 6.6 reports the median male real wage by region from 1992 to 2008, using VHLSS commune survey data. Although real wages were consistently lower in the northern regions than in the southern regions, regional wage differences narrowed considerably by 2008 . This indicates an increasingly spatially integrated national labor market and fast transmissions of wage increases in certain regions based on increases in the cost of labor in other regions.

\section{Factors Associated with Use of Machines}

The descriptive analysis above provides several indicators that the growth of mechanization between 1992 and 2008 had been driven by multiple factors. More formal analysis of the factors associated with machine use are presented in Table 6.7 (see appendix for the estimation method). In column (1), for years 1992-1998, we do not detect significant association between farm size and machinery adoption, likely due to low adoption rate overall. In the other two columns, representing later years, farmers with larger holdings are more likely to use machines, consistent with scale economies of machinery adoption. Machine use does not respond to real agricultural wage in columns (1) and (2). 
TABLE 6.6 Real median daily wage of male agricultural labor, Viet Nam, 1992-2008 ('000 VND)

\begin{tabular}{lrrrrrr}
\hline Region & 1992 & 1998 & 2002 & 2004 & 2006 & 2008 \\
\hline Red River Delta & 7.49 & 14.41 & 13.59 & 15.28 & 19.90 & 28.06 \\
Northeast & 5.16 & 11.17 & 11.00 & 13.00 & 15.78 & 22.22 \\
Northwest & 6.96 & 9.05 & 9.28 & 9.38 & 14.48 & 18.66 \\
North Central Coast & 7.67 & 12.12 & 12.96 & 13.22 & 19.95 & 23.58 \\
South Central Coast & 7.34 & 15.56 & 14.39 & 16.17 & 17.60 & 23.51 \\
Central Highlands & 9.21 & 13.40 & 13.38 & 13.89 & 18.46 & 26.53 \\
Southeast & 11.44 & 15.70 & 17.26 & 17.14 & 21.60 & 25.63 \\
Mekong River Delta & 15.01 & 18.69 & 17.51 & 19.04 & 22.41 & 25.53 \\
\hline
\end{tabular}

Source: Authors' calculations based on Vietnamese Household Living Standard Survey. Note: VND = Vietnamese dong.

In contrast, machine use significantly increases the real wage in column (3), suggesting efficiency improvements in rural factor markets.

\section{Market Institutions in Mechanization Service Provision}

This section briefly summarizes the evolving modes of machinery suppliers and mechanization service providers in Viet Nam. Overall, recent patterns suggest that the private sector has been transforming both markets.

\section{Agricultural Machinery Manufacturing}

As was mentioned above, the growth of the supply of power tillers in the domestic market during the 1990s had been led by the growth in domestic manufacturing, although some power tillers had also been imported. By the end of the 1990s, 5,000-6,000 power tillers were already being domestically manufactured annually by major manufacturers such as Vikyno and Vinapro (JICA 2000), which were leading manufacturing of diesel engines and other machinery (Hien, Khanh, and Quick 2007). Some power tillers were domestically manufactured using a diesel engine fitted into a scrap chassis (Starkey et al. 2002, 57). ${ }^{5}$ By 2001, Viet Nam had started exporting tractors (mostly power tillers) (FAO 2018).

5 In Viet Nam, the use of the small engine for multiple types of small machinery was started indigenously by domestic engineers who saw the potential of changing the use of the equipment for power boats and axial flow pumps in the 1960s (Sansom 1969; Stewart 1974; Biggs and Justice 2015), and later on power tillers. 
TABLE 6.7 Regression results on machine use

\begin{tabular}{lccc}
\hline & $(1)$ & $(2)$ & $(3)$ \\
Variable & Sample years & Sample years $=$ & Sample years $=$ \\
\hline Log total area of rice (all varieties) & 0.00234 & $0.0968^{\star \star \star}$ & $0.0540^{\star \star}$ \\
Log male real ag. wage (VND in 1992) & $(0.0258)$ & $(0.0317)$ & $(0.0235)$ \\
& -0.0729 & 0.0730 & $0.103^{\star \star}$ \\
Male household head (yes = 1) & $(0.101)$ & $(0.0513)$ & $(0.0436)$ \\
& -0.0675 & -0.0308 & -0.0221 \\
Age of household head & $(0.0447)$ & $(0.0776)$ & $(0.0197)$ \\
& -0.000305 & -0.000135 & -0.000412 \\
Highest education of household members & $(0.00110)$ & $(0.00205)$ & $(0.000565)$ \\
& -0.0000498 & 0.00359 & -0.00202 \\
Number of male members & $(0.00749)$ & $(0.00851)$ & $(0.00637)$ \\
& $0.0403^{\star}$ & -0.0114 & 0.00208 \\
Household size & $(0.0215)$ & $(0.0286)$ & $(0.00824)$ \\
Year dummy & $-0.0282^{\star \star}$ & 0.00489 & 0.00609 \\
Observations & $(0.0138)$ & $(0.0190)$ & $(0.0103)$ \\
\hline
\end{tabular}

Source: Authors' calculations based on Vietnamese Household Living Standard Survey.

Note: Asterisks indicate the statistical significance: ${ }^{\star \star \star} 1 \%,{ }^{\star \star} 5 \%,{ }^{\star} 10 \%$. Standard errors in parentheses. VND $=$ Vietnamese dong.

Although there is no direct evidence, the importation of power tillers in the 1980s may have resulted in local adaptations and eventual manufacturing. For example, in the late 1980s, Daedong Industry Co. in the Republic of Korea started exporting power tillers and farm engines to Viet Nam via barter trade-gaining a foothold in communist countries (Lee 2007). Similarly, Tongyang Moolsan Co. supplied power tillers and farm engines to Viet Nam and was recognized by the Vietnamese government for its technology (Lee 2007).

Domestic manufacturing also accounted for 30 percent of combine harvesters (Viet Nam, MIT 2015), which are mostly the domestic production of Kubota combines by Kubota Viet Nam Ltd. (the rest were often manufactured in China and exported to Viet Nam). Direct evidence on how industrial policy in Viet Nam has led to growth in the domestic manufacturing of combines is scarce, but anecdotal evidence suggests that domestic manufacturing 
of harvesters and reapers originally promoted by the Vietnamese government has gradually declined. ${ }^{6}$

Rice milling machines are mainly manufactured in the country by companies such as Bui Van Ngo, Lamico, and so on, with rice processing lines that have a capacity of 4-40 tons ${ }^{7}$ per hour, and grain dryer arrays of 30-200 tons per batch. Bui Van Ngo's product quality is world-class (comparable to Japanese Satake, which is one of the major suppliers of modern rice milling machines globally and in the Asia region), and Bui Van Ngo has exported rice equipment to about 20 countries in Asia, the Americas, and Africa.

Manufacturing of engines in Viet Nam has also grown. Today, diesel engines from 5 to $30 \mathrm{hp}$ can be produced domestically, with an annual production capacity of 40,000 units, approximately 30 percent of domestic market share. In addition, about 2,000 provincial medium-size or small mechanical workshops deal with fabrication, trial, sale, and repair of machines. The leading manufacturer, Viet Nam Engine and Agricultural Machinery Corporation (VEAM), has also exported engines. VEAM is a large state-owned company with reported assets around $\$ 600$ million $^{8}$ in 2014 and was recently converted into a joint stock entity in 2016. VEAM has seven large factories throughout Viet Nam and has set up a national network of dealers for its $2 \mathrm{WTs}$, engines, and other machinery. It inherits the old-time support for heavy industries and has some advantages over private companies in terms of loans and investment. However, to be competitive in the manufacturing of machines, the company should have a solid basis in modern metallurgy, which is severely lacking in Viet Nam. Thus, even with a large inventory of machine tools and production capacity, VEAM has just played a modest role in supplying machinery for agriculture.

\section{Machinery Supply}

In Viet Nam today, tractors are largely marketed by the private sector, which supplies both new and used machines, provides repair and maintenance

6 Before the growth of combine harvesters in the 2010s, manufacturing of reapers and minicombines had grown temporarily (Hien, Khanh, and Quick 2007). Reaper manufacturing in Viet Nam peaked in 1988 with about 15 manufacturers, which had gradually declined to 3 by 2000, producing 100-200 units per year each (Hien, Khanh, and Quick 2007). Mini-combine harvesters that could harvest around 1 ha per day had been developed in a public-private partnership between the Philippine Rice Research Institute and Briggs \& Stratton. Around 700 machines were produced by Vinapro in Viet Nam through 2009 (Pandey et al. 2010, 338). Most of these mini-combines were bought by private farmer-contractors with their own money. "Tons" refers to metric tons throughout the chapter.

8 Dollar amounts are in US dollars throughout the chapter. 
services as well as some extension and training, and offers credit services for prospective machine owners. Vietnamese-manufactured power tillers (Vikyno, Vinapro, and so on) have been substituting for imported power tillers since the 1990s. Domestic manufacturers have been expanding their supply networks and likely providing spare parts. The Japanese company Kubota has been making inroads into the Vietnamese market for 4WTs and combine harvesters. In fact, new Kubota 4 WTs are competing against old Kubota tractors (Kubota Corporation 2011). Kubota tractors sold in Viet Nam are, however, modified to be much stronger and more durable than those used in Japan. This is because although there is only one production season per year in Japan, Viet Nam typically has two or three production seasons per year, and tractors are used extensively throughout the year.

The private sector has also largely been supplying combine harvesters. Although harvesters originally promoted in Viet Nam generally did not spread quickly, Chinese combines have been increasingly adopted, particularly between 2006 and 2009, because these Chinese companies also provided after-sales services and spare parts. Gradually, the Japanese Kubota combine, with a generally smaller harvest loss rate, ${ }^{9}$ has overtaken the Chinese combines. By 2013, Kubota's share in the Vietnamese combine harvester market had reached 75 percent. Concurrently, the number of Vietnamese manufacturers fell from 15 to 3, with 15 percent market share (Gummert et al. 2013). Kubota's dealers and network have grown to supply machines, after-sales services, and repair and maintenance services.

\section{Custom Hiring Service Provision}

Historically, three major types of tractor/combine harvester owner and service provider arrangements have existed in Viet Nam: (1) individual ownership, (2) government-run systems, and (3) cooperatives-run systems.

(1) INDIVIDUAL OWNERSHIP

In southern Vietnam, individual ownership and service provision was the most common form of ownership before 1975. In the 1960s, larger farmers who had received increased income from using water pumps and new varieties were then able to invest in further labor-saving technical innovations, such as rototillers and tractors (Wiegersma 1988).

9 Currently, three types of Kubota combine harvesters with the typical cutting width of about 1.5-2.0 $\mathrm{m}$ are popular (MIT 2015): the DC-35 (35 hp), which harvests about $0.1-0.3$ ha per hour, and the DC-60 (60 hp) or DC-70 (70 hp), which harvest about $0.3-0.7$ ha per hour. 
In the late 1970s, after the reunification of the country, individual ownership of tractors, tillers, threshers, pumps, and draft animals was abolished, and these were sold to the provinces at values below market prices (Pingali and Xuan 1992), with the intent of making the local governments and cooperatives the major providers of services.

However, such measures were relatively incomplete, and many individual owners remained in business in southern Viet Nam. The diffusion of cooperatives in southern Viet Nam was generally limited; only 6 percent of farmers in the Mekong River Delta belonged to cooperatives in 1986, compared with more than 90 percent in northern Viet Nam (Pingali and Xuan 1992). Despite the law, villagers still owned substantial stocks of nonland capital, such as water pumps or small tractors, and provided services to lower-middleincome and poor peasant cultivators, or to the agricultural cooperatives, on a contractual basis (Van Luong and Unger 1988; Gorman 2014).

After Resolution No. 10 was instituted in 1988, initiating the process of decollectivization, ${ }^{10}$ tractor plowing services were privatized, although in some cases the services remained the responsibility of the collectives (Kirk and Tuan 2009). Individual ownership began growing again in southern Viet $\mathrm{Nam}$, as well as in northern Viet Nam. Initially, tractors were purchased from the cooperatives that used to own them. The new individual tractor owners often had diverse backgrounds. For example, individuals in Quang Binh province purchased tractors from cooperatives, using the private savings accumulated through various activities such as a duck-raising business (Quan 2009). Households studied by Quan (2009) in Quang Binh had invested 21 million Vietnamese dong (or VND; about \$1,400) from their own savings on a small tractor in 2004, which was primarily used for moving the mobile saw used for wood processing. Other studies indicate that in some cases, manure collectors also purchased tractors and gradually replaced human and buffalo carts (Peters et al. 2004).

By 1999 , tractors were predominantly owned by individual farming households -88 percent for large tractors, 97 percent for power tillers, and 98 percent for diesel engines (JICA 2000), and this prevalence of individual owners had further deepened by 2007-94 percent of tractors greater than $35 \mathrm{hp}, 98.5$ percent of those 12-35 hp, and 99.7 percent of those less than 12 hp (Viet 2014). In Viet Nam today, 2WTs are widely used and account for the majority of tractors. The low cost of 2WTs suggests that ownership is not

10 Resolution 10 obliged the agricultural cooperatives to contract land to peasant households for 15 years for annual crops and 40 years for perennial crops (Kirk and Tuan 2009). 
solely restricted to wealthy households, but they are also affordable to middleincome households. As a result, the roles of cooperatives that allow joint ownership of tractors may be less significant. There has also been a significant decrease in the price of land preparation services after small tractors (12 hp) were introduced and replaced big tractors $(50 \mathrm{hp}$ ).

Figure 6.10 plots the probability that a farm household provides tractor rental services, conditional on rice planting area, among 789 tractor owners, aggregated from three rounds (2004, 2006, and 2008) of the VHLSS. Larger rice farmers are more likely to provide rental services. This is primarily because larger farmers are generally still more likely to own tractors (albeit with relative growth of tractor ownership among smaller farms, as illustrated in Figure 6.3) for use on their own farms, but also for earning profits from hiring out to neighboring farms.

\section{(2) GOVERNMENT-RUN SYSTEM}

Government-run agricultural machine stations were set up under the Communist Party in the 1980s, with the aim of providing affordable mechanization services to farmers and cooperatives. By 1983, agricultural machine stations were set up in 200 districts throughout the country, which could potentially handle 30 percent or more of the tilling of the arable lands in the country (US Department of Commerce 1983), slightly more than the actual area tilled by tractors in 1980 (27 percent). Additionally, 120 stations for minor repairs of tractors and 45 maintenance workshops were created throughout the country with Soviet assistance. By May 1983, 200 "machine collectives" and 100 "machine cooperatives" had been set up in southern Viet Nam, with a fleet of 3,200 tractors (Marr and White 1988, 167). In 1984, at the Sixth Plenum of the Central Committee (Fifth Congress), a plan was developed to transfer control of agricultural support stations and agencies dealing with tractor operations, irrigation, farm implement factories, and so on from the provinces to the districts (Vasavakul 2015). By 1985, there were about 300 district-level agricultural machine stations (previously called tractor stations) with a fleet of approximately 20,000 tractors of various sizes and more than 20,000 tractor operators-primarily tasked with providing tilling services for agricultural cooperatives (US CIA 1985).

In the early 1980s, some cooperatives still found it cheaper to hire draft animals from contractors rather than hire tractors from a district hiring station (White 1982). The incentive structures for station workers, as prescribed in government directives in 1982, had not been properly implemented, and workers were poorly incentivized, insufficiently compensated, and not 
FIGURE 6.10 Proportions of samples providing tractor rental services, conditional on rice planting area, among tractor owners, Viet Nam, 2004-2008

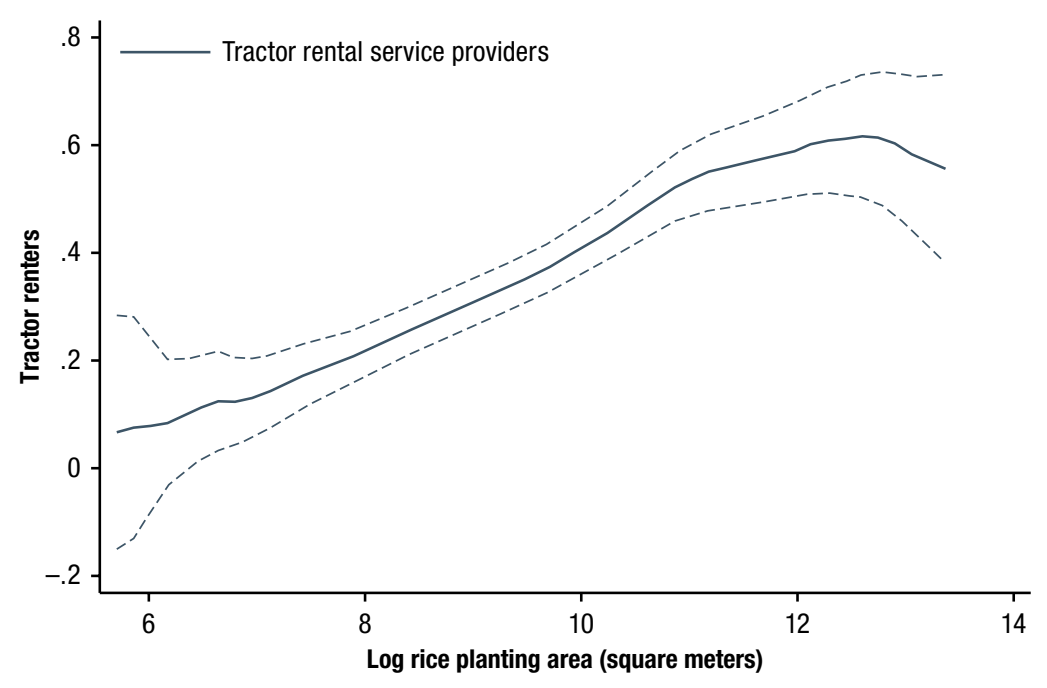

Source: Authors' calculations based on Vietnamese Household Living Standard Survey.

Note: Dashed lines are 95\% confidence intervals.

provided with adequate protective equipment (US CIA 1985). The efficacy of these government-run systems was evident in the resulting closure of all the district tractor stations in Viet Nam by 1990 after the market reforms of the late 1980s (Tan 2011).

\section{(3) COLLECTIVES AND COOPERATIVES}

After the decollectivization that started in 1988, collectives gradually transferred the ownership of tractors to individuals (though some cooperatives still owned tractors), but these cooperatives still played important roles in coordinating land preparation. In the early 1990 s, cooperatives in northern Viet Nam often used riding tractors to provide primary plowing and harrowing services to groups of villagers, who would then apply secondary plowing using private animals or tractors from individual contractors (Kono and Doan 1995).

Under the new cooperative law, many former "agricultural production collectives" had been converted to "service cooperatives" (Scott 2008). This process was mostly complete by 2005 (Quan 2009). The main services of new cooperatives included the management of the irrigation systems and the 
electricity-generating facilities, the supply of farm inputs, field preparation, extension, and the marketing of outputs (Wolz 2000; Quan 2009).

These newly converted cooperatives provided hiring services through their own tractors or acted as an intermediary between farmers and individual tractor owners (often called contractors) (Takahashi 2015). Contractors were usually a local group serving households within their commune with members contributing capital to buy their own tractors and some receiving government support to purchase tractors. ${ }^{11}$ When contracting with individual tractor or buffalo owners, cooperatives often relied on competitive bidding, with a ceiling price for the land preparation service predetermined by the representatives of the members of the cooperatives (Quan 2009). In other cooperatives, several board members jointly invested in tractors and received dividends from the profit earned through hiring (Takahashi 2015).

\section{COMBINE HARVESTER SERVICE PROVIDERS}

Information on combine harvester ownership and service provision is generally limited. However, anecdotal evidence suggests that the individual farmerto-farmer model is quite common in Mekong River Delta, where 75 percent of combine harvesters in Viet Nam were located as of 2014 (Viet 2014), the most common being the Japanese Kubota. Many Kubota combine owners are wealthy large farmers, cultivating 20-100 ha annually. In Mekong River Delta, 20 percent of Kubota combine owners cultivated more than 100 ha in 2011 (Kubota Corporation 2011). These combine owners hire out their services, earning several hundred million Vietnamese dong ( $\$ 10,000$ or more) per year after deducting costs (Kubota Corporation 2011).

\section{Relatively Weak Government Involvement during Mechanization Growth Phase since the 1990s}

In Viet Nam, as in some other Asian countries, the government's direct policies toward mechanization followed the growth rather than led it for the period up to the 1990s, when mechanization substantially took off. For example, information on subsidies in Viet Nam up to the period of the 2000s is limited, suggesting that subsidies were not widely provided. Only in 2009 did the government take a proactive policy on mechanization through Resolution

11 Communes are the lowest governmental administrative units in Viet Nam. A commune is usually a homogeneous community in terms of topography and livelihood activities. The concept of a modern commune relates more to the term "community" than to the idea of collective ownership. Typically, there are between 15 and 35 communes in a district, and within a commune there are typically 5 to 10 villages or "hamlets" (Quan 2009). 
48/NQ-CP, which aimed at reducing rice postharvest losses from the current 11-13 percent loss down to a 5-6 percent loss by 2020 (Nguyen and Hien 2014). Decision 68/2013/QD-TTg ${ }^{12}$ in 2013 and Decision 08/2014/ TT-BNNPTNT in 2014 addressed credit policies to reduce postharvest losses and to improve mechanization in postharvest operations, aiming for providing subsidies on interest rates for selected machines and equipment, provided to cooperatives, farmers' groups, households, and individuals (listed in that priority order).

Other policies had been implemented in the past, but had relatively limited effects on the growth of mechanization. For example, the National Center for Testing of Agricultural Machinery issued permits for locally mass-produced or imported equipment. However, after 1990, this agency became self-financed with a reduced role and scope (no longer in charge of southern provinces) and was renamed Center for Evaluation of Machines and Equipment. The agency liberalized the applications of diverse machinery in agriculture, but it also allowed for more low-quality imported secondhand machines that were unsuitable for production and resulted in losses to farmers using these machines.

\section{Conclusions}

Viet Nam has reportedly experienced rapid growth in agricultural mechanization lately. However, available information about the historical growth patterns of mechanization in the country has been rather vague. Significant knowledge gaps exist regarding the actual extent of mechanization, the heterogeneity of adoption patterns across regions and farm sizes, and the characteristics of emerging suppliers of machines and hiring services.

As far as tractors are concerned, available evidence indicates that tractor adoption rates in Viet Nam had reached moderately high levels by 1980 (close to 30 percent of the entire country and even higher in Southern Viet Nam), albeit under a very different sociopolitical system than today. Future studies must investigate how such exposures might have contributed to the resurgence of tractors in the 1990s.

Substantial public investments including those in agricultural research and development and in irrigation infrastructure, as well as the acceleration of the economic transformation in the country, are likely to have stimulated the

12 Government documents may be downloaded from http://vanban.chinhphu.vn/portal/page /portal/chinhphu/hethongvanban?class_id=18mode=detail\&document_id=170904. 
demand for increased farm power use after the economic and social reforms in the late 1980s. The mechanization patterns have been highly divergent across regions, characterized by growth in the smallholder-dominated deltas and the land-abundant regions of the central coast. Machine use has been largely enabled by rentals rather than ownership. Whereas machinery use and tractor ownership have been originally concentrated among larger farmers, they have gradually spread to smaller farms, enabling many smallholders to stay competitive in the face of rising farm wages. However, the past few decades have also seen an increase in the areas cultivated annually for crops such as rice through increased production frequency enabled by the expansion of irrigation infrastructure. Mechanization growth is likely to shift the comparative advantage of farming toward larger farms, where land market development may become increasingly important.

Since the economic and social reform in the late 1980s, the private sector has rapidly emerged as the major player in meeting the demand for greater farm power use in Viet Nam. The fast pace of growth of the power tiller manufacturing industry during the 1990s and the shift from smaller combines to larger combine harvesters in the last several years are largely consistent with the predictions in earlier literature (for example, Binswanger 1986) that the supply side is generally not a major constraint for mechanization growth in developing countries, compared with the demand-side constraints, even in transition countries such as Viet Nam.

As for policy recommendations to Africa, Vietnamese experiences offer the following lessons. First, as described above, significant investments in public goods, including complementary seed technologies and irrigation infrastructure that were partly expanded during the socialist regimes, played important roles in stimulating demand for tractor plowing. Second, the significant involvement of government in tractor hiring services intensified during the 1980s through collectivization, and generally did not lead to significant tractor use growth. Similar attempts in African countries, in which the government selects the potential hiring service providers, are likely to face similar challenges. Instead, the growth of hiring service providers should be left to the market. Third, once the demand for mechanization had risen, partly through the aforementioned investments in the development of complementary technologies and irrigation and road infrastructure, the liberalization of the economy in the 1990s led to considerable growth in mechanization use and domestic manufacturing of 2WTs. It is likely to be important for African countries to follow such dynamics in the sequence of public goods investments and market promotion in order to stimulate mechanization adoption growth. 


\section{References}

Biggs, S., and S. Justice. 2015. Rural and Agricultural Mechanization: A History of the Spread of Small Engines in Selected Asian Countries. IFPRI Discussion Paper 01443. Washington, DC: International Food Policy Research Institute.

Binswanger, H. 1986. “Agricultural Mechanization: A Comparative Historical Perspective.” World Bank Research Observer 1 (1): 27-56.

FAO (Food and Agriculture Organization of the United Nations). 2018. FAOSTAT database. Accessed April 27. http://faostat.fao.org.

Foster, A. D., and M. R. Rosenzweig. 2011. Are Indian Farms Too Small? Mechanization, Agency Costs, and Farm Efficiency. New Haven, CT, US: Economic Growth Center, Yale University.

Gorman, T. 2014. "Moral Economy and the Upper Peasant: The Dynamics of Land Privatization in the Mekong Delta." Journal of Agrarian Change 14 (4): 501-521.

GSOV (General Statistics Office of Vietnam). 2016. Vietnamese Living Standard Survey and Vietnamese Household Living Standard Survey. Hanoi, Vietnam.

Gummert, M., P. H. Hien, T. V. Khanh, and M. A. Kyaw. 2013. Combine Harvesting in South and Southeast Asia: Current Status and Trends. Los Baños, Philippines: International Rice Research Institute.

Hien, P. H., T. V. Khanh, and G. R. Quick. 2007. "Development of Rice Combines in Viet Nam.” Electronic-only proceedings of the International Conference on Crop Harvesting and Processing, Louisville, KY, US, February 11-14. http://opensourceecology.org/wiki /Combine_Research_Paper\#Development_of_rice_combines_in_Viet_Nam.

IRRI (International Rice Research Institute). 1978. Proceedings of the International Agricultural Machinery Workshop. Los Baños, Philippines.

- 1983. Consequences of Small-Farm Mechanization. Los Baños, Philippines.

— 1986. Small Farm Equipment for Developing Countries. IRRI. Los Baños, Philippines.

JICA (Japan International Cooperation Agency). 2000. Vietnam: Report by Agricultural Development Survey Team (Nogyo-Kaihatsu Kiso Chosa-dan Hokokushu). Report submitted to JICA. Tokyo.

Kienzle, J., J. E. Ashburner, and B. G. Sims. 2013. Mechanization for Rural Development: A Review of Patterns and Progress from Around the World. Rome: Food and Agriculture Organization of the United Nations.

Kirk, M., and N. D. A. Tuan. 2009. Land-Tenure Policy Reforms: Decollectivization and the Doi Moi System in Vietnam. IFPRI Discussion Paper 927. Washington, DC: International Food Policy Research Institute. 
Kono, Y., and D. T. Doan. 1995. "Effect of Water Control on Rice Cultivation in the Red River Delta, Vietnam: A Case Study in the Nhue River Irrigation System." Southeast Asian Studies 32 (4): 425-445.

Kubota Corporation. 2011. "The Bountiful Mekong Delta: Vietnam Catches the Wave of Mechanized Farming." Global Index, 7-18. www.kubota.com/globalindex/backnumber /pdf2011_en/gi-e-3.pdf.

Lançon, F., D. Sautier, and D. T. Anh. 2014. Vietnam: Rural Connectivity and Agriculture Logistics in Domestic Market Supply Chains_Synthesis Report. Washington, DC: World Bank.

Lee, Y. H. 2007. “Trade of Agricultural Machinery in Korea.” Mimeo.

Liu, Y., W. Violette, and C. Barrett. 2016. Structural Transformation and Intertemporal Evolution of Real Wages, Machine Use, and Farm Size-Productivity Relationships in Vietnam. IFPRI Discussion Paper 01525. Washington, DC: International Food Policy Research Institute.

Mandal, S., S. Biggs, and S. Justice. 2017. Rural Mechanization: A Driver in Agricultural Change and Rural Development. Dhaka, Bangladesh: Institute for Inclusive Finance and Development.

Marr, D. G., and C. P. White. 1988. Postwar Vietnam: Dilemmas in Socialist Development. Ithaca, NY, US: Southeast Asia Program, Cornell University.

Minot, N., and F. Goletti. 2000. Rice Market Liberalization and Poverty in Vietnam. IFPRI Research Report 114. Washington, DC: International Food Policy Research Institute.

Nguyen, B. T., J. W. Albrecht, S. B. Brogman, and D. M. Westbrook. 2007. “A Quantile Regression Decomposition of Urban-Rural Inequality in Vietnam.” Journal of Development Economics 83: 466-490.

Nguyen, L. H., and P. H. Hien, eds. 2014. Rice Post-Harvest Technology in Viet Nam. English Translation and Update. Hanoi: Agricultural Publishing House.

Pandey, S., D. Byerlee, D. Dawe, A. Dobermann, S. Mohanty, S. Rozelle, and B. Hardy. 2010. Rice in the Global Economy: Strategic Research and Policy Issues for Food Security. Los Baños, Philippines: International Rice Research Institute.

Peters, D., N. T. Son, N. B. Mui, and P. N. Thach. 2004. "Piglet Enterprise Assessment and Improvement in Cat Que Commune, Vietnam." Livestock Research for Rural Development 16 (2): $1-19$.

Pingali, P. 2007. “Agricultural Mechanization: Adoption Patterns and Economic Impact." In Handbook of Agricultural Economics, edited by R. Evenson and P. Pingali, 2779-2805. Amsterdam: Elsevier.

Pingali, P. L., and V. T. Xuan. 1992. "Vietnam: Decollectivization and Rice Productivity Growth." Economic Development and Cultural Change 40 (4): 697-718. 
Quan, T. 2009. “Transition from Subsistence Farming to Commercial Agriculture in Quang Binh Province, Vietnam." Doctoral dissertation, Lincoln University, Jefferson City, MO, US.

Reardon, T., K. Chen, B. Minten, L. Adriano, T. Dao, J. Wang, and S. Gupta. 2014. “The Quiet Revolution in Asia's Rice Value Chains." Annals of the New York Academy of Sciences 1331: 106-118.

Sansom, R. L. 1969. “The Motor Pump: A Case Study of Innovation and Development." Oxford Economic Papers 21 (1): 109-121.

Scott, S. 2008. "Agrarian Transformations in Vietnam." In The Political Economy of Rural Livelihoods in Transition Economies: Land, Peasants and Rural Poverty in Transition, edited by M. Spoor, 175-199. Abingdon, Oxfordshire, UK: Routledge.

Starkey, P., S. Ellis, J. Hine, and A. Ternell. 2002. Improving Rural Mobility Options for Developing Motorized and Nonmotorized Transport in Rural Areas. Technical Paper 525. Washington, DC: World Bank.

Stewart, F. 1974. “Technology and Employment in LDCs." World Development 2 (3): 17-46.

Takahashi, F. 2015. "Business Activities of 'Transformed' Agricultural Cooperatives and Their Role in Supporting Local Agriculture in Northern Vietnam." International Journal of Environmental and Rural Development 6 (2): 87-93.

Takeshima, H., Y. Liu, N. V. Cuong, and I. Masias. 2018. Evolutions of Agricultural Mechanization in Vietnam: Insights from the Literature Review and Multi-Rounds of Farm Household Survey Data. IFPRI Discussion Paper 01724. Washington, DC: International Food Policy Research Institute.

Tan, P. V. 2011. "Agricultural Machinery in Logistics and Supply Chain of Rice Production: A Challenge for Vietnam.” Unpublished slides, Southern Institute of Agricultural Engineering and Post-Harvest Technology, Ho Chi Minh City, Viet Nam. http://slideplayer.com/slide /2382011/.

Tsukada, K. 2012. "Mechanization of Rice Farming in Mekong Delta." In Rural Development in Vietnam - Transformation of Rural Economy under the Fast Economic Growth, edited by S. Sakata. Chiba, Japan: Institute of Developing Economies.

Tuyến, N. Q. 2013. “Outcomes of Vietnam’s Agrarian Policies after 'Doi Moi': A Case Study of Attempted Agricultural Intensification and Diversification in a Village in Vietnam's Mekong Delta." Global Journal of Human Social Science Arts and Humanities 13 (6): 37-47.

US CIA (Central Intelligence Agency). 1985. Southeast Asia Report. Springfield, VA, US: Foreign Broadcast Information Service.

US Department of Commerce. 1983. Southeast Asia Report. No. 1372. Springfield, VA. 
Van Luong, H., and J. Unger. 1998. "Wealth, Power, and Poverty in the Transition to Market Economies: The Process of Socio-Economic Differentiation in Rural China and Northern Vietnam." The China Journal 40: 61-93.

Vasavakul, T. 2015. "Vietnam: Sectors, Classes, and the Transformation of a Leninist State." In Driven by Growth: Political Change in the Asia-Pacific Region, edited by J. W. Morley, 59-82. Abingdon, Oxfordshire, UK: Routledge.

Viet, N. Q. 2014. “Status of Custom Hiring in Vietnam.” In 2nd Regional Forum on Sustainable Agricultural Mechanization in Asia and the Pacific: Enabling Environment for Custom Hiring of Agricultural Machinery. Beijing: Centre for Sustainable Agricultural Mechanization, United Nations Economic and Social Commission for Asia and the Pacific.

Viet Nam, MIT (Ministry of Industry and Trade). 2015. Vietnam Manufacturing Supporting Industry Yearbook 2014-2015. Hanoi.

White, C. P. 1982. "Socialist Transformation of Agriculture and Gender Relations: The Vietnamese Case.” IDS Bulletin 13 (4): 44-51.

Wiegersma, N. 1988. Vietnam: Peasant Land, Peasant Revolution: Patriarchy and Collectivity in the Rural Economy. New York: St. Martin's Press.

Wolz, A. 2000. "The Development of Agricultural Co-Operatives in Vietnam Since Transformation." Issue 72 of Discussion Paper. Research Centre for International Agrarian \& Economic Development. Heidelberg, Germany.

Yamauchi, F. 2016. "Rising Real Wages, Mechanization and Growing Advantage of Large Farms: Evidence from Indonesia." Food Policy 58: 62-69.

Zhang, X., J. Yang, and T. Reardon. 2017. "Mechanization Outsourcing Clusters and Division of Labor in Chinese Agriculture." China Economic Review 43: 184-195.

\section{Appendix 6A: Empirical Model}

Results in Table 6.7 are estimated through the following fixed-effects panel equation:

$$
d_{m i t}=\delta_{0, m i}+\delta_{1} \ln \mathrm{w}_{m t}+\delta_{2} \ln a_{m i t}+\delta_{4} \mathrm{z}_{m i t}+\delta_{5} D_{t} \times R_{i}+\epsilon_{m i t},
$$

where $d_{m i t}$ is a dummy variable indicating machine use for household $i$ in commune $m$ and year $t$. It takes a value of 1 if the household owned any tractors or spent on machine rentals and 0 otherwise. $\ln \mathrm{w}_{m t}$ is $\log$ male agricultural wage (in real terms); $\ln a_{m i t}$ is $\log$ rice planting area; $\delta_{0, m i}$ is a household fixed effect that captures time-invariant household and location-specific effects such as 
land quality and weather; $z_{m i t}$ is a vector of household-specific time-varying characteristics; $D_{t}$ is a year dummy; and $R_{i}$ is a vector of regional dummies. We include the region-year fixed effects to capture region-specific time-variant effects (such as interest rates, output and input prices, and public policies, which are assumed uniformly across communes within one region for year $t) ; \epsilon_{m i t}$ is the error term. We cluster standard errors at the commune level. Equation (1) is estimated using the 1992-1998 panel, 2002-2004 panel, and 2006-2008 panel of the VHLSS separately. 
